\title{
A DOUBLE ROLE OF HOUSE WIVES: PRACTICAL STRATEGIES TO BACK UP FAMILY
}

\author{
MASWITA \\ Universitas Al-Azhar, Medan, Sumatera utara, Indonesia \\ maswita30@gmail.com
}

\begin{abstract}
This gender study focused on the roles of women in Batubara Regency of North Sumatra Province of Indonesia. Women's multiple duties are known as mothers and workers. This study aims to analyze the strategies undertaken among women housewives in playing a double role in coastal areas of Malaka Straits. This research was conducted in the village located in the costal area of Batubara Regency, Indonesia. The ethnographic method was conducted with a participant observation and in-depth interviews on selected respondents based on snowball and direct observation in the study area. This study concluded that women have their own strategy to supplement family income, especially to fulfill the need for family food pattern. The strategy of women housewives is a real force although hidden in the routine activities of women as housewives.
\end{abstract}

Keywords: Gender, women, roles, family incomes, Batubara Regency

\section{INTRODUCTION}

The focus of the study on the role of women as a housewife in taking care of family food, and working outside in coastal areas of Malaka Straits.This paper sought the position of some women in North Sumatra in which women's experience in helping the family economy needs was studied to understand the female position in taking care of family. So far, various technology advances takes the women roles. In the formal sector, Indonesian women become judges, prosecutors, teachers, lecturers, staff and civil servants, legislators and others. In the informal sector women also involve in trade, labor and small enterprises.

The domestic roles of wives in Indonesia make them take less part in the past; women are often associated with domestic duties. Women's activities in the domestic room are related to the nature or biological of women. Gamble (2010) mentions women as basically referring to individuals who have a certain set of biological characteristics, including the ability to give birth. The position of women is not the same as that of men in society. In contrast to the woman who is attached to her domestic space, men are quite the opposite. Much of the decrease in the gender gap for unpaid work is due to women investing less time in domestic duties (Oláh, 2014). Men are regarded as appropriate figures in the public sphere. Subordination occurs in the community, so that women are more appropriate in the domestic space (Fakih, 2003).

Social studies show women have been playing outside the home (Gough, 2016). This study reported in the Asia-Africa region that men and women work together in their agricultural areas for family purposes. Such as the fishermen involve their wives work outside home, even though the task of wives selling the catch of fish of their husbands. This shows that coastal fishermen's wives have been able to reflect their ability to meet family needs.

After the Indonesian Social Reform in mid-1998 the women's empowerment movement increased in line with the proliferation of other Social Institutions Society that brought the mission of women empowerment. Empowerment of women then becomes a program that promoted its application into social system as one of community welfare effort. Along with that the role of women becomes complex, it is in the domestic space and also in the public space. Therefore, the dual role of women becomes a concern for society and social experts. The attention of women to special families on child care becomes less, if the mother works outside the home. Davidson's (1992) study of women housewives working outside the home suggests a role conflict. Women who combine role in family 
and role of worker will face role conflict. According to Davidson and Copper (1992) also Powell and Graves (2003), women work dealing with various forms of problems at work and also at home.

The roles of Indonesian women in making sure housing keeping, rare children and workings are needed to study Women work at home also check the principle of complementary variety of food stuffs ensures balanced and adequate food. In terms of family food, the role of women housewives becomes important. Women are powerful in determining the pattern of family food, while community groups have a habit of eating on certain types of food. The influence of food and physical development (UNICEF Indonesia, 2012), there is very little study of the role of women in family food patterns, though women are very influence in the family diet. This study concerning with roles of women as house wives and women's economy back up power in rural areas; "Women's Economics: the contribution of women housewives for backing up the family economic needs".

\section{THEORETICAL REVIEWS ON ROLES OF WOMEN}

In most developing countries like Indonesia, women are traditionally involved in three types of productive work; in the production of household goods, the production of food to be sold or marketed, and outdoors for wages. With technological advances and transformation of the economic system, the relative role of women in the economy has changed. The women who used to be involved in the independent economic system and as the husband's assistant in the family economy and also the unpaid labor. Now women are looking for jobs outside the home and entering industries and companies.

Female laborers have been increasing since 1990 in Indonesia. Wijayanti's (2010) study of female factory workers explained that their income was used for family purposes. There are even many families in Indonesia that depend on the income of women (Namora, 2007). Herawati (2010) concluded that the female laborers that female income is so important to the family economy. Forty percent $(40 \%)$ of family income is female income. The contribution of women to the family economy is an assessment of the family so that the assessment of men also needs to be done. To analyze gender in economic activity, it should not be separated from family analysis. Setiadi (2011) said there are unbalanced facts about activities based on gender. The case originated from unsuitable opportunities and community resources. The sources include power to materials, rewards given by others, decisive roles, free time, food and health care, personal autonomy, opportunities for education, training and freedom from violence (Sanderson, 2003).

In the study of Herien (2012) found that the purpose of working wife is to improve family welfare. They use income from economic activities to meet family needs. The Herien (2012) investigation also resulted in subjective wellbeing perceived by the wife. Wives are satisfied with what they do in generating the economy. The subjective well-being of the family is defined as life satisfaction based on personal success (Chen, 2010). Women's involvement in the informal economy becomes a special feature of developing countries. This case was found by and Chen (2004) in their study of developing countries. The economic activities that women enter are jobs on the streets such as clear and open activities, and invisible activities such as sewing, snacks and other marginal activities. This activity is done at home or in a closed place without any connection with formal activities. Studies and observations make it clear that women fall into the category of people most affected by the economic crisis (Harriet et al, 2014). However, women cannot allow themselves to be unemployed, they must meet family needs. Therefore, they do other work as long as they earn income to be used to meet family needs (Liliane, 2015).

Women's involvement in the informal sector is not balanced with the formal sector. This is shown from 40 percent of women and 60 percent of men work in the informal sector while 32 percent of women and 68 percent of men work in the formal sector. In the micro commerce sector, the existence of women is very meaningful for the economic development of the country. There are 30 million small and medium entrepreneurs, and 60 percent of them are women (Central Bureau of Statistics, 2009). One reason for the increase in female labor is the family's economic needs. The Ony (2011) investigation found that economic problems are an important factor for women to work. Working outdoors and having income alone is their goal to achieve an improvement in diet. 
Aondoseer (2015) found that the motivated wives work were to meet basic needs for survival. Wolfman (1992) said that an important factor, the motivation of women choosing to work is the economic need, although there are other factors other social scholars, such as Christina (2010) who reviewed women in the village. They say that the husband's income is the main factor women play a role in the economic field so that women look for alternatives to get job. Always, the field of women in the village was chosen as a worker or laborer. The needs of working women can be classified in three factors. The main factor is the family economy, the two have no other work and the third is supported by the family.

Agricultural systems by men and women have shown the different duties and roles of men and women in families and households. The division of duties between women and men has contributed to the family's agricultural output, although in agricultural work there is a difference between men's and women's work. Women have played a role in the economic field from the very beginning since the existence of the agricultural system (Hirschman, 2016).

\section{RESEARCH METHOD}

This research used ethnographic design. An ethnographic methodology has the potential to add value to studies of interaction by contributing a sustained engagement in local cultural contexts (Litts and Searle, 2015). The respondents in this study were housewives who work in domestic work and work in non-fomal economics. Respondents were determined as many as 16 people selected based on the snowball technique. This research was conducted in Sukamaju of Batubara Regency of North Sumatra with consideration: the villages where samples lived have been in the Progress Plan of Batubara Regency. The data collection was an observation and in-depth interview techniques. The results of the study were analyzed qualitatively led to be ethnographic report.

Table 1. Respondents profile

\begin{tabular}{|c|c|c|c|c|}
\hline Respondent & Age & Education & Job & Husband's job \\
\hline Wan & 48 & Primary school & Cleaning Fish & Fisherman \\
\hline Mas & 39 & Primary school & Cleaning Fish & Fisherman \\
\hline Ruk & 34 & $\begin{array}{l}\text { Junior High } \\
\text { School }\end{array}$ & Cleaning Fish & Fisherman \\
\hline Rid & 49 & $\begin{array}{l}\text { Jun i or High } \\
\text { School }\end{array}$ & Cleaning Fish & Fisherman \\
\hline Sid & 30 & $\begin{array}{l}\text { Junior High } \\
\text { School }\end{array}$ & Cleaning Fish & Fisherman \\
\hline Id & 69 & No School & Selling vegetables & Fisherman \\
\hline Piy & 71 & Primary School & Selling Clothes & $\begin{array}{l}\text { Gover } \mathrm{nm} \text { e } \mathrm{nt} \\
\text { employees }\end{array}$ \\
\hline Nit & 50 & $\begin{array}{l}\text { Senior High } \\
\text { School }\end{array}$ & Whole seller & Fisherman \\
\hline In & 35 & Primary School & Retailer & Fisherman \\
\hline Nid & 30 & Diploma 1 & Selling Salted Fish & Fisherman \\
\hline
\end{tabular}




\begin{tabular}{|l|l|l|l|l|}
\hline Aj & 49 & Primary School & Peeling Shells & $\begin{array}{l}\text { G o v e r n m e n t } \\
\text { o f f i c e r } \\
\text { Employees }\end{array}$ \\
\hline
\end{tabular}

\begin{tabular}{|l|l|l|l|l|}
\hline Lin & 48 & Primary School & Peeling Shells & Fisherman \\
\hline $\mathrm{Ni}$ & 37 & Primary School & Peeling Shells & Fisherman \\
\hline $\mathrm{Su}$ & 36 & $\begin{array}{l}\text { J u n i r H i g h } \\
\text { School }\end{array}$ & Making Cake & Fisherman \\
\hline Id & 24 & $\begin{array}{l}\text { J u n o r H ig h } \\
\text { school }\end{array}$ & $\begin{array}{l}\text { Making Cake } \\
\text { S e n or H ig h } \\
\text { school }\end{array}$ & $\begin{array}{l}\text { S t o r e h o u s e of } \\
\text { Fisherman }\end{array}$ \\
\hline Ic & 38 & Storehouse Seller \\
\hline
\end{tabular}

\section{RESEARCH RESULT}

The phenomenon of women working to fulfill family needs is a special feature of developing countries. Results of the study indicate that women's involvement in the economic ; women have successfully fulfilled the economy. In this context, women independently mobilize their family economy, resulting in a change in family income. Women in Batubara Regency used their incomes to back up family cash.

\section{Women's Economic Strategy}

The strategy undertaken by women is not choosing the type of work that exchange jobs from one to the other type of work. There are 4 types of work they are: cleaning fish, peeling the shells, selling and making cakes. In addition, respondents also have a strategy in managing income with grocery shopping for families. The study indicated that the respondents did not choose certain types of work in economic activities. For the income factor, the respondents main were having sidedjobs. An interview with Rid, she works to clean fish. Although Rid has been graduated of Junior High School, she works for the fish production. Before married, Rid had worked as a restaurant waiter in town. But for the sake of the family, she sincerely works as cleaning fish. She told the investigator:

"I work as cleaning fish is to increase the family economy. If I choose the type of work in this village I certainly do not have a job. The work of the fisherman with the waiter is very different. The restaurant waiter's job is cleaner and tidier, wearing a uniform, dressing up and always communicating with the visitors who come. While job of cleaning fish is less clean and slightly dirty and cause odor. Clothes worn dirty and eyes focus on the fish alone (Rid)".

Another information from NIT; she has been graduated of high school, but NIT works to make cookies. She makes the cakes every day to meet family needs. Another one was AJ (respondent) works pilling shells; she never worked in the economic field. Despite the work of a civil servant's husband, she feels the need to work. At the beginning of Aj's work, his friends sneered at her for such a bad wife of civil servants working to peel the shell. For $\mathrm{Aj}$, it does not need to be listened because the purpose of work is to supplement family income.

The result of the study from the respondent Lin shows that Lin works by the encouragement of the respondent AJ. They both always talked about grocery shopping. The husband's income from fishing not fixed; it is the reason for Lin to help family income. AJ invited Lin to work as a solution for family income. Fishermen incomes very dynamics; sometimes low sometimes too high, high income is about IDR150.000, and low income is about IDR30.000, per week. Not only family necessities in food, 
children's schooling is also important so Aj's invitation becomes a boost for Lin's respondent to work. After two years Aj worked, respondent Lin also worked with respondent Aj. Lin told investigators; I work for my children and my family. My husband's income can only buy rice and sugar alone. To buy side dishes and vegetables always owed in the shop, not to mention for school children. While my friend Aj worked even though her husband was a civil servant that was not enough. If I work one day at a time it can be IDR12.000 so it's IDR18.000. With my own income, I am more freely buy food for my son (Lin).

For Wan, other respondent, family opinion is important for family purposes. Working on anything is not something that is inappropriate, that's why Wan worked to clean fish. If she does not work to clean fish, she helps selling used-clothing (monza) business, help House chores. Respondent Wan go to work every day. Sometimes Wan also does irregular job.

Information from Nid showed Nid does not work in the formal field, whereas Nid has a computer Certificate. Nid works in the non-formal field of selling salted fish. Nid needs to increase family economy, so as not to rely on the husband's economy alone. Nid's income from selling salted fish is quite good, so it requires workers. Nid's husband offers his services to delivery salted fish. Her husband said to take the driver or assitant would require a salary. The problem of Nid husband was revealed, at first working to sell salted fish.

The analysis to the respondent Lid, it proved that the school education does not always get a job in the formal sector. Lid did not despair, although for two years she was looking for formal work in accordance with her education. Through the announcement in Batubara regency, Lid had tried to apply to become a civil servant. The civil servant remains her top choice, other than the honorarium in Batubara District. Finally Lid got married. For two years of marriage she received husband's income alone. The incomes were used for the whole day cannot be saved though the savings are necessary for the future of children. The study of Lid can be concluded that Lid is indeed young in age. But the strategy for a decent and future life is hers. She understands that the decision to sell cakes has risks to house chores for childcare. So she sold the cake in front of his house.

The decision to choose the work of making the cakes also was found in the life of $\mathrm{Su}$, a high school diploma holder. After two years of school she didnot get a formal job, she finally made her own cake shop; homemade cakes. The work of making cakes based on her own skill.In contrast, Su's mother was making cookies. In contrast to Nis, she was peeling shells for seven years.

\section{Shifting Job Stategy}

The study found, in addition to respondents did not choose the type of work, some of respondents also shifting from one job to another type of works. It aims to achieve the needs of family life. Although up to now the income of the work has not been able to achieve the goal of prosperous families, but there has been a change in the family economy.

Irespondent ID was interviewed about shifting strategy, was born at the end of the colonial era and she did not complete elementary school.

At the time of this study she sold vegetables in the morning. Before selling vegetables, she helps her husband as a fisherman. She has been selling vegetables on the market outside Sukamaju, Batubara Regency. From the results of the respondent's income, it is known that every material sold, there is certainly a profit. In addition to profits in the form of money, profits are also obtained in the purchase of vegetables for her family. ID had more profit than buying food. The business of ID has not got the benefit sometimes. However, ID was happy because she was no longer hit by wind storms and sea waves when she was in the sea to help her husband. Id way of shifting job,not money bases but the wish..

In terms of working in the field of economy is also shown by the respondent PIY; she was not young anymore; even her friends who are in same age with her has passed away. Earlier, Piy never worked, she only worked in housework only. The job of selling cloths is Piy's choice to supplement the family 
economy. She is motivated to realize family needs in different types of food and balanced. At that time, the husband's income as a civil servant could not meet the need. Actually, Piy sold the cloth in a state forced to meet the demands of children with regard to the pattern of food. The courage of Piy selling cloth is a form of encouragement to her whereas she never works in the field of commerce. Before she decided to do a business, she discussed with his friends who also work selling cloth. Piy's conversation was about environment, the way of shopping materials, how to sell and so on.The rest of the sales such as vegetables, fish and fruits can be eaten by the family so that the grocery shopping for the family becomes cheaper.

The study to respondent Sid, she has worked before marriage. She did not continue her education to the rank of Senior High School because she was encouraged by friends who already work and have their own income. For respondents Sid money earned from own income is better than asking the parents. That's why she works as a waiter in a tin shirt. Age 20 years after four years of her work she married. Sid has three sons. Sid elaborates with joy when she is 30 years old. The eldest child is already in the third grade of elementary school. She can provide different food patterns and different daily meals to her family. The strategy Sid worked with was the fish, although the work was not the kind of work she had ever lived.

The results of the study to the respondents Mas who worked the fish memorable elementary school, her husband's income as a fisherman IDR20.000 a day are not sufficient for family purposes. The type of work that is easily available in the area is to fish. Although a little bit smelly and dirty Mas does not worry about it. Mas had never worked since the girlhood. This is done to fulfill the needs of family Mas. Income is earned to buy rice, sugar and vegetable oil. Rarely do the other side dishes except fish catch her husband as a small fisherman. Likewise with Ruk respondent, as girls are used to work. Before married Ruk worked as a clerk, Graduated from junior high school she tried to work in order to have her own money. Not dependent on his parents. After married Ruk realizes that the husband's income alone is not enough for family needs. Not to mention for the purposes of school children, for the purposes of eating it is always owed in the store. That's why Ruk must work with the fish, although her work is not clean.

\section{Grocery Shopping Strategy}

Shopping for groceries is an activity that requires a strategy. This is related to the price expected by the female respondent. The skill of a housewife woman in terms of grocery shopping is needed to manage family income. This relates to efficiency rather than income. In the respondents, they have a way and strategy to get the price of food that is cheap and still qualified. Shopping strategy they do is shopping wholesale and shopping by adjusting prices on certain days.

\section{Wholesale Shopping Strategy}

One strategy was to manage groceries. The study of wholesale shopping was found in the information of Aj, Rid, Su, Mas and Ruk. Wholesale shopping can be done in the afternoon, so it is getting cheaper and giving benefits doubled. In general, the market where they shop opened from morning until late afternoon. In the afternoon the market will be finished, the sellers will sell their wares cheaply, because tomorrow they will sell the new stuff. Su is an respondent; she shops wholesale shopping in the afternoon. To save the food he bought a used refrigerator at a cheap price. Unlike Rid's respondent, she is shopping for a little bit limited to a certain type. Usually done he is a kind of side dishes, such as eggs and fish. Eggs can survive 15 to 25 days if stored in the refrigerator. Other ingredients are fruits such as sweet oranges and bananas. Sweet oranges are selected in varied categories, there are oranges that have yellow color and some are still greenish. Yellow orange was eaten so the green color will turn yellow.

Respondent Mas, to manage the food in the wholesale, she first cooked the food easily wilted. For the type of chili she picked his stalk first then wrapped in newsprint and stored in the refrigerator while the type of onions are placed in a container and get light. Side dishes and vegetables and fruits are placed in the refrigerator. If the husband brings his catch fish then respondent Mas groups the fish in the category directly eaten and stored in the refrigerator. Side dishes are eaten gradually. Same with Ruk respondent, she also shops wholesale. If the type of fish is cheap then Ruk buy the fish. To keep 
the wet fish steamed with salt, then put it in the refrigerator so that it lasts longer. Things like steaming fish are also done by Ruk if the husband brought the fish catch. Ruk said although the husband of the fisherman rarely bring the fish catch to the house, because toke they always sell all the fish. Usually vegetables that are easily damaged he cooked first, such as spinach and watercress. While for carrots, pumpkin japan and cabbage more durable will be cooked the next day. What Ruk does is also carried out by respondents $\mathrm{Aj}$. She shopped wholesale and arranged the groceries to be used for food.

\section{Grocery Shopper Strategy}

Shopping means to adjust the price is a cheap type of grocery shopping on a certain day. The respondent buys foodstuffs on the market based on food prices. The study to Wan's information found that Wan was a low school educated housewife. Though she worked the fish and his husband worked the fishing sector. Ways and strategies of grocery shopping were one of Wan's abilities. She goes to market every day to adjust his family's income to the prices of food items that day. She manages her shop even though she is busy in housekeeping activities and the work of the fish. Wan told investigators;

For example, Monday, I want to buy a type of fish side dish, type of green mustard greens and sweet orange fruits for my family's diet. But the price of fish side dish is expensive on that day. I will not buy fish, the kind of side dish I exchange to tempe and tofu or chicken or egg or salted fish if the day is cheap. Type of vegetables and fruit types as well as I do. Therefore I shop for family meals every day. (Wan)

For Wan', shopping by adjusting for the price, is the right way to get food at a cheap price. Wan shopping for groceries is not based on food to be cooked but based on the price of the type of food on a given day. On certain days the types of fish side dishes are expensive, but the price of the type of tempeh, tofu and eggs is cheaper. So she will not buy fish for a side dish, she bought the soybean permentation (tempe), tofu or egg. Types of chicken side dishes are also always changing. Sometimes the price of chicken meat is cheaper than fish. In contrast, fish prices also always change in the types of fish. For the Wan respondent, the price of vegetable type is still the type of kale and the leaves of sweet potato, while the price of vegetable type comes from the mountain such as green mustard greens, chicory, carrots, japan gourd, beans, white radish, and other vegetables are always changing. Such a price situation becomes the basis for Wan's rocery shopping. She said occasionally the price of green mustard vegetables is very cheap, namely IDR1.500 for one $\mathrm{kg}$, carrots IDR3.000 for one $\mathrm{kg}$ and so forth. Occasionally the price of green mustard vegetables is expensive so IDR12.000 for one $\mathrm{kg}$, and carrots IDR15.000 for one $\mathrm{kg}$. Every day the food pattern of Wan's family is tailored to the price of the food on a particular day.

In addition to Wan's respondent, Lin's respondent also arranges grocery shopping by adjusting. Every day Lin goes to the market to shop for groceries by deciding what kind of food is bought at a cheap price on a given day. According to Lin;

Actually, the type of side dish that is always cheap is tempeh, tauhu, eggs and chicken meat.

However, after the country imported soybean from outside the price of tempeh and tofu

becomes expensive and changing. Vegetable prices also vary each day. I buy pumpkin vegetables or pumpkin water, or kale or sweet potato leaves if other vegetables are expensive. Fruits that are always cheap are citrus fruits, watermelons, pineapples, and mangoes are fruits whose prices are fixed. It is very rarely expensive. (Lin).

Sid's respondent also did the same with Lin and Wan. Instead she felt tired to spend every day, but this must be done to get the price of cheap food. Sid told investigators;

I am not rich, but I try to give the best food for the family. The most important thing in managing family needs is in the case of grocery shopping. Important for me is the family to eat in a balanced meal. (Sid).

\section{The Role of Women's Economy on Family Patterns.}

The economic role of women in terms of family food needs attention of experts. Kadocsa (2011; Enik, 2012) found that food is related to the mother's work and the economic status of the family. Muhammad (1998) argued the necessity of foodstuffs has a central place in the socio-economic life of the family. Through family income is exchanged for the type of food. Hidayat (2009) argued that the 
income greatly determines the quality and quantity of dishes. The more income means the better the family food. This means, the higher the income, the better the food pattern eaten by the family.

In the study found, women as wives and mothers in working families are an attempt to save the family economy, especially in terms of food purposes. Hughes (2008) found in his study of farmers that other family experts such as children or wives were important factors in saving the family economy.

Review to respondent Rid, she said the husband's income as fisherman IDR100.000, - during the sea three days. While Rid's income IDR 10.000 one day thus the family income from the husband IDR30.000, -including Rid income IDR10.000 per day to IDR40.000. Rid's habit of organizing consumable expenditures is grocery shopping, since eating with one type of side dish is enough. With Rid's respondent income, he can buy vegetables and fruits.

The income of the respondent The fish mast was used to buy the family food. Husband's income cannot be guaranteed to buy food items. Then income is to buy only basic ingredients of rice and side dishes, sugar and vegetable oil for one day salary husband respondent Mas IDR20.000 so IDR30.000 only. For the purposes of the kind of side dishes, the respondent Mas always carries the catch fish. Mas work always get salary IDR12.000, - one day. It can be used to buy vegetables and fruits. For Ni respondents also, husband's income as a fisherman cannot accommodate to buy vegetables and fruits. For that respondent Ni works to peel shells so that the purposes of the type of food are fulfilled both vegetables and fruits.

In contrast to the respondent In, she can get an advantage of shop business doubled from IDR30,000 to IDR60,000 a day. In addition to having its own income, vegetables and fruits which not sold can be used for family. This is certainly a cheap price because she bought the ingredient in many to be sold in garbage. Family In always eat in a balanced diet, there are types of side dishes, types of vegetables and types of fruit. In never thought about how much revenue the husband, she was hard to tell their husbands, because their husbands as fishermen with an income of IDR18,000 to IDR36,000 a day. In the case of an adequate amount for family purposes at least IDR60.000 a day.

\section{CONCLUSIONS AND SUGGESTIONS}

Various ways and strategies of respondents in Batut Bara Regency to increase incomes in performing a double role as followings: Women's strategies are not only working in the informal economy, but they are good at managing family food expenditure in various ways. Strategy such as choosing work and shifting from work to other types of work was performed by respondents, bisede their efforts were to generate income. Respondents were strong in generating revenues to save the family economy. Therefore, any effort such as how to shop for food; achieving family food patterns of different types of food reaveled the women in a double role. Shopping in the afternoon and shopping by adjusting the price is the effort made to adjust the income and food expenditure is a savings in spending for the purposes of the pattern of food economically and is met.

\section{REFERENCES}

Aondoseer, A., Umar K., Odekina A. Felicia. (2015). Family Factors And Women Entrepreneurial Motivation In Nigeria: A Survey Of Selected Women Entrepreneurs In Kogi State. Proceedings of the IRES 19th International Conference, Dubai.

Central Bureau of Statistics, (2009). Small and medium entrepreneurs https://bps.go.id/Brs/view/id/ $\underline{811}$

Chen. (2010) Intergenerational Social Support and the Psychological well-being of Order parents in China. Res Agung. 12(2), 43-65.

Christina, W.T (2010). Work Ethic and Social Life of Profession Economics. Community Journal. 2 (2), 31-53.

Davidson, J. K. \& Moore, N. B. (1992) Marriage and Family, Wm. C. Brown Publishers, Dubuque.

Enik, S. \& Ali R. (2012). The Role of Education and Employment of Mothers in the Consumption of Pre-School Vegetables. Journal of Nutrition University of Muhammadiyah Semarang, 1(1).

Fakih, M. (2003) Gender As a social analysis tool. in analyzing gender in understanding women's issues. Journal of Social Analysis. 4th Edition, 7-16. Bandung; AKATIGA 
Gamble, S. (2010). Introduction to understand feminism \& post feminism. Yogyakarta: Jalasutra.

Gough, N. (2016). Australian outdoor (and) environmental education research: Senses of "place" in two constituencies. Journal of Outdoor and Environmental Education, 19(2), 2-11.

Harriet, T., Nana A.O, Asare, E.K.A. (2014). The Role of Women in Reducing Household Povertyin the Bongo District of the Upper East Region, Ghana. Journal of Arts and Humanities (JAH), 3(4), 99-110

Hidayat,A.A. (2009). Introduction To Basic Human Needs. Jakarta: Selemba Medika

Hirschman, Charles. (2016). Gender, the Status of Women, and Family Structure in Malaysia. Malaysian Journal of Economic Studies 53(1): 33 - 50

Herawati. (2010). Discriminatory and exploitative contractual work practices and labor outsourcing in the Indonesian metal industry sector. Bandung: Akatiga.

Herien Puspitawati . (2012). Gender and family: Concepts and reality in Indonesia. Accessed: http://ikk.fema.ipb.ac.id/v2/images

Hughes, D. W., C.B. Stacy M., \& Tom M. (2008). Evaluating the Economic Impact of Farmers' Markets Using an Opportunity Cost Framework. Journal of Agricultural and Applied Economics, 40(1): 253-265

Liliane, U.K. (2015). The Impact Of Women Economic Empowerment Projects On Their SocioEconomic Development In Rwanda: The Case Of Agaseke Project. European Journal of Business and Social Sciences, 4(6), 59-87

Litts, B. K. \& Kristin, S. (2015). Design Ethnography or Ethnographic Design Research?: How to Engage Youth and Communities. Center for Socially Engaged Design

Muhammad, A.(1998). Belief and Practice Eating Malays Malaysian Peria River Kelantan Malaysia. (Tesis PhD unpublished). UKM

MPR Decree Number IV/Mpr/1978 of 1978 on Outline of State Policy (GBHN)

Namora, L.L. (2007). Catholic Women In Feminist Studies. Medical magazine Nusantara. 40 (1), 5.

Oláh, L.S., Rudolf, R. \& Irena, E. K. (2014). The new roles of men and women and implications for families and societies. Family and Society Working 11, 1-40.

Ony. L.\& Dian, K.H. (2011). The Relationship Of Education And Work Of The Mother Father And The Pattern Of Nurturing With The Nutritional Status Of Toddlers in Tangerang, Banten. Proseding Penelitian Bidang Ilmu Eksakta.

Powell, G.N. \& Graves, L.M., (2003), Women and Men in Management. Thousand Oaks: Sage.

Sanderson,K.S. (2003). Macro Sociology: An Approach to Social Reality. Jakarta: Radjawali Press

Setiadi.,E.M. (2011). Introduction to Sociology: Understanding Facts and Symptoms and Social Issues: Theory, Applications and Its Solutions. Jakarta: Kencana.

UNICEF Indonesia. (2012). Health of both mother and child. Summary of the Study.

www.unicef.or.id. February, 15, 2014.

Wijayanti, D.M. (2010). Shackles Poverty Women Workers Cigarette Factory. Community Journal. 2(2): 84-93.

Wolfman.B.S. (1992). The role of women: how to be proficient and balanced. Various Roles. Yokyakarta: Kanesius 